\title{
Strategic Analysis of Bus Rapid Transit System in Improvement of Public Transportation: Case of Tehran, Iran
}

\author{
Hamid Mohammad-Beigi ${ }^{1}$, Jafar Nouri ${ }^{1} \&$ Humman Liaghati ${ }^{1}$ \\ ${ }^{1}$ Department of Environment, Science and Research Branch, Islamic Azad University, Tehran, Iran \\ Correspondence: Hamid Mohammad-Beigi, Department of Environment, Science and Research Branch, Islamic \\ Azad University, Tehran, Iran. E-mail: hmohammadbeigi2015@gmail.com
}

Received: March 8, 2015

Accepted: March 13, 2015

Online Published: August 30, 2015

doi:10.5539/mas.v9n9p169

URL: http://dx.doi.org/10.5539/mas.v9n9p169

\begin{abstract}
Urban transportation is one of the principal and significant elements of urban system that supplies the accessibility of citizens to different requirements. Growth of population in large cities of Iran especially in its capital, Tehran and as a result of city expansion and transportation growth have been caused many environmental problems. So, public transportation specifically Bus Rapid Transit (BRT) is suitable solution for solving these problems. This paper, tried presents required strategies to improve transit oriented development in the use of BRT in Tehran using SWOT technique through strategic planning. In this paper surveys and field studies have been used to determine the strengths, weaknesses, opportunities and threats with to results of provide strategies to improve BRT of Tehran. Analysis shows that BRT after to 6 years operation has effective and beneficial, social, economic and environmental impacts in Tehran. Indeed, the public satisfaction about BRT is high in this city.
\end{abstract}

Keywords: BRT, strategic planning, SWOT, public transportation, Tehran

\section{Introduction}

Cities have vital important role in developing of economic (Dill, 2006). This development depends on physical, social and educational substructures (Cain and Dario, 2009). Then inter transportation in cities is the most important factor in life of a city and important for citizens to attain the goods and services. In the other way, need of transportation in many large cities is increasing continuously because of natural increasing of the people and immigrations. Availability of motorized transportations increases the income of families and affects all the economy activities. One of the problems in cities is delay in transporting people in the cities (Gwillian et al., 2010). This will increase the cost. The main reason of this problem is the unbalance in the distribution model and insufficient substructure of transportation. Also the most important reason of pollution is transportation systems (Evans, 2004). So, we need a sustainable transportation in cities for less destruction in the environment and covering most social needs. Fig. 1 shows a simple model for sustainable transportation (OTTP, 2010; FTA, 2009).Bus Rapid Transportation (BRT) in one of the most economical solution in public transportation systems (Cheng et al., 2007; Chang and Huang, 2006; Lusk, 2001). BRT is combination of all good solutions for increasing speed of buses (Miller and Buckley, 2008).

BRT system can transport people with a high speed and good quality in a network. However it is not long time past from starting this system, it has high potential to make basic changes in city transportation (Syed and Khan, 2000). Furthermore BRT is a high quality transport solution, safe, comfort and rapid in for people transporting (Liman, 2010; McNally et al., 2003). This solution is comparable with rail transportation (Levinson et al., 2003).Tehran as capital of IRAN with 8.7 million people has important role in 3 aspects: National, Region and Local (Pourmoallem et al., 2008; Hiroyuki, 2008) and has basic problems in city transportation (Table 1). Vision of comprehensive transportation plan which shows the future of transportation of this city in 2020 expresses that the transportation of the city will meet the international standards (Municipality of Tehran, 2004).This integrated system will be well running, comfort, safe, clean and good available in the way of economic development of Tehran which is practical solution according to limited resources (Bolghari, 2004). In the past 6 years the mega city Tehran has started operation of BRT in many areas (Zamanian et al., 2010). 
Table 1. Public transport and traffic situation in the Tehran-2012

\begin{tabular}{cc}
\hline Status & Year 2012 \\
Average daily travel speed & 17 \\
Average travel time & 26.5 \\
Average latency compared to the travel time & 25.1 \\
The number of public transport trips & 51.1 \\
The average travel time by public transport & 8.4 \\
Average travel speed on public transport & 15.5 \\
The share of public transport trips & 23.2 \\
The share of rail transport(metro) in the travels & 54.5 \\
The Share of $\quad$ transportation with taxi in travels & 10 \\
The Share of $\quad$ transportation with bus in travels & 23 \\
Transportation's share of administrative services, training, etc. & 21.5
\end{tabular}

SWOT analysis shows the strengths, weakness, opportunities and threats. This simple and easy tool can show the global status of the system. The analysis helps to make decisions and it can be used as a guide for strategic planning. Strengths and weakness are internal and opportunities and threats are external elements (Kajanus et al., 2004). SWOT is attained usually by interview and questionnaire (Leung et al., 2001).

\section{Method}

\section{Study Area}

Tehran is the biggest center of politics, economics and culture in IRAN and the largest human residence and a mega city. This city is located in $51^{\circ}-4^{\prime}$ to $51^{\circ}-33^{\prime}$ E., and $51^{\circ}-4^{\prime}$ to $51^{\circ}-33^{\prime}$ N. (TTST, 2007). This city is located between Mountain and desert in south of Alborz Mountains from 900 to 1800 meter height from sea surface (Deputy of Urbanization and Architecture, 2007). The area of this city is 750 kilometer square (Municipality of Tehran, 2004). Fig. 2 shows the location of Tehran. As preview of people, the status of BRT in 153 kilometer in Tehran was attained. The research was done by questionnaire through 500 people from random users of BRT in the inner of the buses. The samples are as Fig. 3 in the route of BRT in order to have a broad spread of the users.

Before doing the research we tested the stability of the questionnaire through (Cronbakhs alpha test). The alpha before doing the test was 0.69 and after deleting two questions we get alpha equal to 0.80 (Table 2). This value according to the least stability value 0.70 is acceptable.

Table 2. Final Exam Questionnaire

\begin{tabular}{cc}
\hline \multicolumn{2}{c}{ Reliability Statistics } \\
\hline No of items & Cronbakhs Alpha \\
19 & 0.800 \\
\hline
\end{tabular}

Based on Likert range, which indicates the importance and sensitivity accountable compared to the factors that set. Used questionnaires and rating results for the compilation and analysis, the questionnaire results was modeled on the basis of SWOT. Used a variety Likert and evaluated 1 to 5 of respondents (Taleai et al., 2009; Kortilla et al., 2000). Ranked the final prioritization factors by respondent's opinion and multiplied every factor 
from 1 to 4 on the basis of rank and importance (Amin et al., 2011). So was determined the final score for each index, and was extracted strengths, weaknesses, opportunities, and internal and external's threats faced by developing of BRT system in Tehran finally.

\section{Results}

In comprehensive plan of Tehran, the population of this city has been prognosticated in too bounds in 2020 .

a) Population bound: 9.1 million people

b) Population bound: inhabitant population: 10.5 million people (Monavari and Aminsharee, 2010).

In the first attitude, the crossing network of Tehran will be 18 million mounted or equal 25.5 movements. Inhabitant stipulate population, 10.5 million people and 17.6 million mounted with $15.6 \%$ daily transportation, and also 3.3 million vacation (Chuanjiao, 2008;TTST, 2006) (fig. 4) transportation vehicle portions in several of Tehran indicates in 2020. Also it illustrates 20.9 or 20.6 million daily transportation in this city, so vehicle portion is $55 \%$ and bus driving $22 \%(\mathrm{CRP}, 2009)$. In spite of Tehran just BRTs constitute $4 \%$ of bus driving network has $44 \%$ Barden for bus driving transportation. So it reveals the enormous quantities of transportation system. The coefficient of seats in bus in Tehran is 35; to compare with taxies is 2.5 and car 1.5 it indicates the significance of that (Afandizadeh and Baghaee, 2008). In according to the intensity of energy in a car driver that is 8 times rigorous than bus, the percentage of providence for energy will be 300,000 liters if the diesel bus will use 7,000 liters (CTBU, 2009).

The manipulation of BRTs in Tehran and the beneficiaries of that:

1) Diminishing the usage if private transportation.

2) Preventing from squandering the time of folks

3) Diminishing traffic jam

4) Accelerating the usage of public transportation

5) Sending the elicit and accurate proofs to the passengers in bus station with a proper timing

6) Taking the tickets before getting to the bus and eliminating the connection between passengers and driver.

7) Decreasing private cars

8) Expecting time for passengers in stations

9) Diminishing the environment pollution

10) Diminishing the expectation times and lingering in stations

So some problems are going to be created after exploitation the BRTs in Tehran:

1) No places of getting the burdens

2) Making Morse lard laconic the transporting areas

3) Using the speed preventing a lot

4) Lack of adequate place for crossing the BRTs buses

5) The connection problem between two streets

6) Not having the easy access for using paralyzing stuff

7) Mounting and landing method

8) Axel rating the traffic jam for private cars

9) No public associating and any estimating for people's needs for planning exerting and setting

10) No security for passengers

11) No programing in a comprehensively way before exerting and evaluating the prosperity or defeating BRTs

12) Closing the comfort zone looking for the passengers and drivers

13) Disturbing in harmony and physiognomy for the city

14) Disturbance in using the environment

15) Problems for arrival and emersion of the private cars that have the authority and the owners in BRTs line

16) The probability of dissatisfaction from exerting BRT plans 
17) Accelerating the tension folks cause of lack of the security

18) People identify thrusting

19) Disorganizing special lines and private lines

20) Problem for getting the utensil and burdens in BRT vicinity

BRT system has the various things running ways, stations, vehicles, fare collection, information transportation system, and services. (fig.5). The special ingredients of lines, transportation, stations and managing the wise systemic in this article going to investigate for analyzing the feebleness opportunities and threat for passengers. Public resolution SWOT for BTR systems in Tehran illustrated in (table 3) the ranked matrix and priority for analyzing and the arranges.

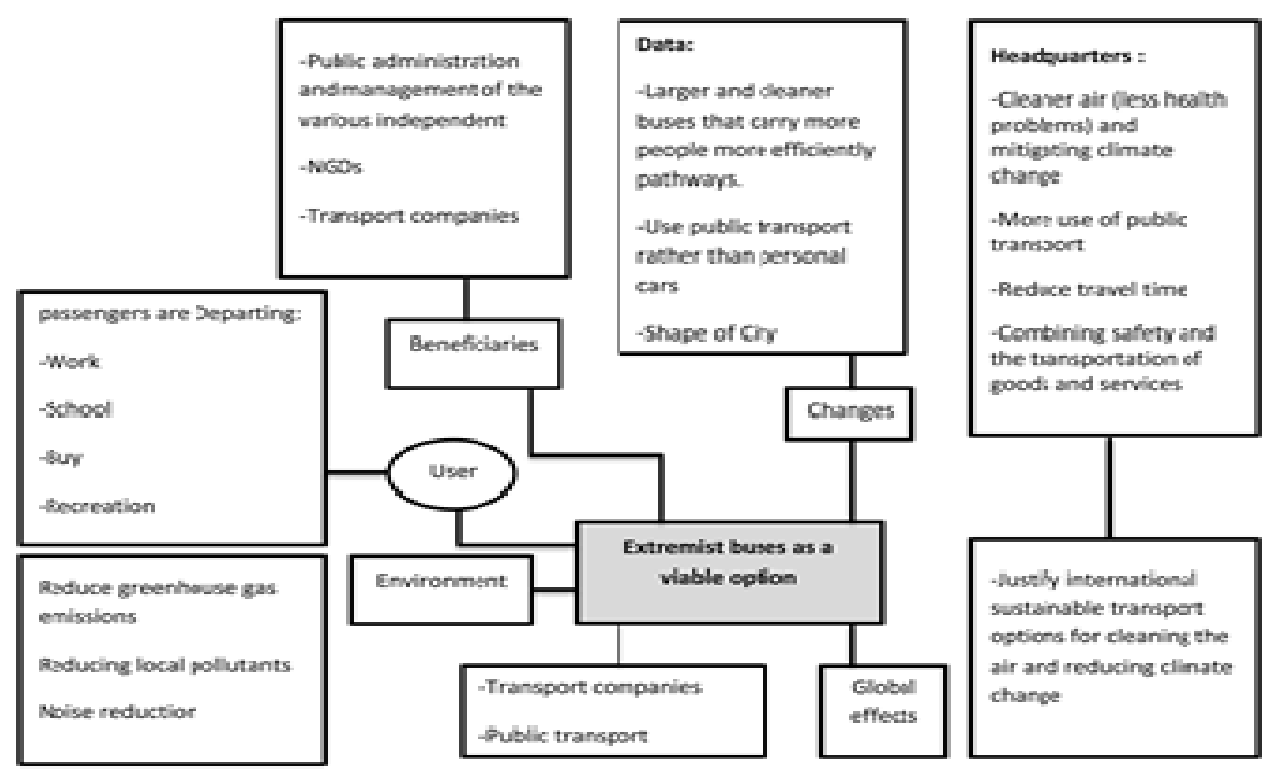

Figure 1. Summary functions of BRT in Tehran

Table 4. SWOT matrix rankings based on respondents' comments about BTR in Tehran 2012

\begin{tabular}{|c|c|c|c|c|}
\hline--- & Strengths & Weaknesses & Opportunities & Threats \\
\hline Environment & $\begin{array}{l}\text {-Reducing local } \\
\text { pollution and } \\
\text { greenhouse gas } \\
\text { through the } \\
\text { replacement of old } \\
\text { emissions buses } \\
\text { - Noise reduction }\end{array}$ & $\begin{array}{l}\text {-Cutting down trees } \\
\text {-Generation of waste } \\
\text { and other pollutants } \\
\text { during the } \\
\text { construction period }\end{array}$ & $\begin{array}{l}\text {-Improving bus fuel } \\
\text { quality } \\
\text {-Improved bus } \\
\text { technology }\end{array}$ & $\begin{array}{l}\text {-Increased use of } \\
\text { personal cars }\end{array}$ \\
\hline Culture and Society & $\begin{array}{l}\text {-Consensus of } \\
\text { passengers } \\
\text {-Reduce travel time } \\
\text {-Reduce disease } \\
\text {-Increased space for } \\
\text { women }\end{array}$ & $\begin{array}{l}\text {-Lack of proper } \\
\text { access for the elderly } \\
\text { and handicapped } \\
\text { - protested people } \\
\text { that Nearby the way } \\
\text {-Passengers } \\
\text { complained about the } \\
\text { crowded bus } \\
\text {-Accidents and Crime }\end{array}$ & $\begin{array}{l}\text {-Educating drivers. } \\
\text { Travelers and } \\
\text { media } \\
\text {-Promotion of public } \\
\text { transport }\end{array}$ & $\begin{array}{l}\text {-Pickpocketing risk } \\
\text {-Damage to stations }\end{array}$ \\
\hline Infrastructure & $\begin{array}{l}\text {-Separate route bus } \\
\text { lines }\end{array}$ & $\begin{array}{l}\text {-Was not crossed } \\
\text { Lines }\end{array}$ & $\begin{array}{l}\text {-Development use of } \\
\text { larger buses }\end{array}$ & $\begin{array}{l}\text {-Destroy ways and } \\
\text { stations }\end{array}$ \\
\hline
\end{tabular}


-Appropriate fare system

\section{Operation \\ Financial \\ Economics}

Politics

-Proper
implementation
Appropriate
-commercial speed
-The full capacity of
passengers
-Receive e-fares

-Low cost infrastructure -Revenue generated by crane

-The role of the environment in the government will be better -use of Improper

asphalt

use of Inappropriate

isolators

-Lack of adequate

capacity for passengers and

-Poor quality of service compared with metro

-it seems that the ticket prices is low -lack of appropriate financial status

-Government priorities on the double-deck buses -Construction of the bypass route is top priority

-Used hydraulic

cement in ways

-Improving access

-Errors in and use of automatic management bus doors

-Improved management rental

-Good relations with other government officials
-Reduced ticket prices

-Lack of attention from government agencies -Change as a result of the recession and stop system

\begin{tabular}{|c|c|c|c|c|c|c|c|}
\hline \multicolumn{2}{|c|}{ ITS Management } & \multicolumn{2}{|c|}{ Special Route } & \multicolumn{2}{|c|}{ Station } & \multicolumn{2}{|c|}{ Vehicle } \\
\hline Ave & rank & Ave & rank & Ave & rank & Ave & rank \\
\hline 437.9 & Wi1 & 461.3 & Ww1 & 506.2 & Ws1 & 417.3 & Wv1 \\
\hline 335 & Wi2 & 442.6 & Ww2 & 471.39 & Ws2 & 285.2 & Wv2 \\
\hline 327.5 & Wi3 & 415.3 & Ww3 & 453.9 & Ws3 & 361.7 & Wv3 \\
\hline 324.7 & Wi4 & 365.4 & Ww4 & 412.6 & Ws4 & 354.9 & Wv4 \\
\hline 315 & Wi5 & 253.2 & Ww5 & 418.5 & Ws5 & 352.7 & Wv5 \\
\hline 254.3 & Wi6 & 250.4 & Ww6 & 386.1 & Ws6 & 318.2 & Wv6 \\
\hline 249.6 & Wi7 & 232.9 & Ww7 & 314.9 & Ws 7 & 318.1 & Wv7 \\
\hline 247.3 & Wi8 & 211.5 & Ww8 & 312.5 & Ws8 & 357 & Wv8 \\
\hline 245.5 & Wi9 & 204.7 & Ww9 & 121.7 & Ws9 & 302.3 & Wv9 \\
\hline 136.8 & Wi10 & 119.5 & Ww10 & 120.5 & Ws10 & 300.7 & Sv1 \\
\hline 127.3 & Wi11 & 472.7 & Sw1 & 114.1 & Ws1 1 & 300.1 & Sv2 \\
\hline 499.6 & Sil & 435.4 & Sw2 & 114 & Ws 12 & 299.7 & Sv3 \\
\hline 244.2 & Oi1 & 282.9 & Sw3 & 107.6 & Ws13 & 298.6 & Sv4 \\
\hline 170.8 & Ti1 & 181.6 & Sw4 & 335.3 & Ss 1 & 295.6 & Sv5 \\
\hline \multirow[t]{2}{*}{151.4} & $\mathrm{Ti} 2$ & 162.2 & Sw5 & 254.3 & Os1 & 288.4 & Sv6 \\
\hline & & 150.7 & Sw6 & 171.9 & Ts1 & 307.1 & Ov1 \\
\hline
\end{tabular}




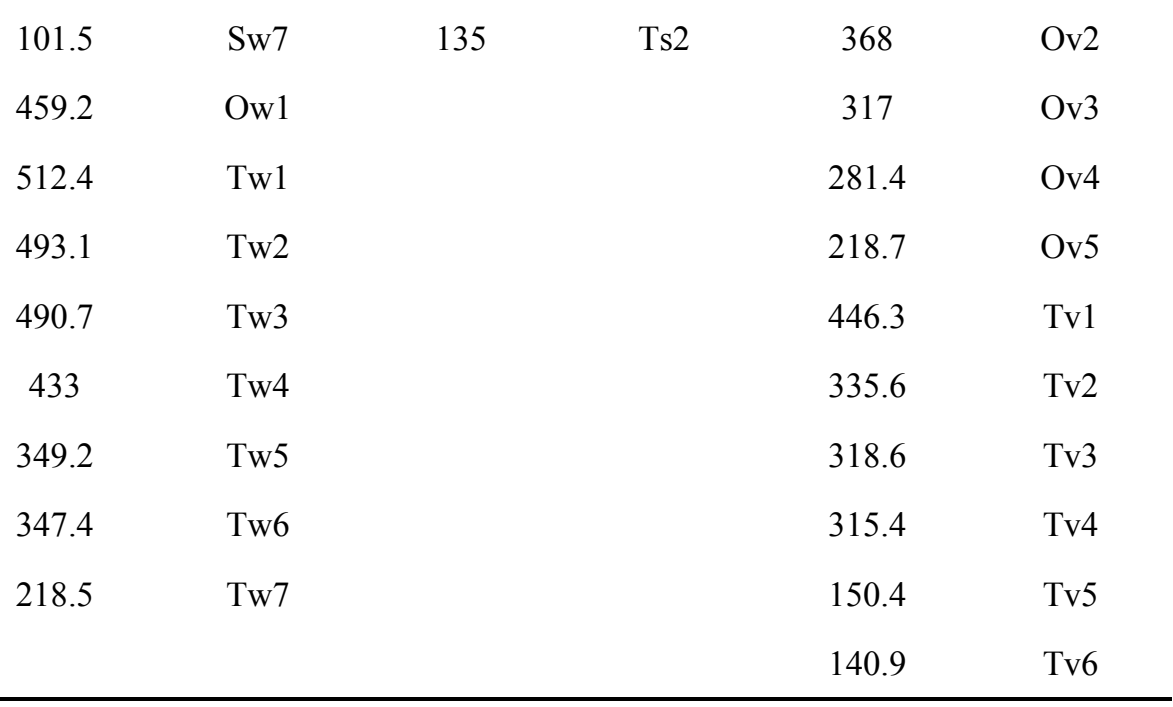

Table 5. Final weight matrix factors influencing Tehran BRT system

\begin{tabular}{|c|c|c|c|c|c|c|c|c|c|c|c|c|c|c|}
\hline $\begin{array}{l}\text { ran } \\
\mathrm{k}\end{array}$ & $\begin{array}{l}\text { Final } \\
\text { weig } \\
\text { ht }\end{array}$ & $\begin{array}{l}\text { Weak-ness } \\
\text { es }\end{array}$ & $\begin{array}{l}\text { ran } \\
\mathrm{k}\end{array}$ & $\begin{array}{l}\text { Final } \\
\text { weig } \\
\text { ht }\end{array}$ & $\begin{array}{l}\text { Weak-ness } \\
\text { es }\end{array}$ & $\begin{array}{l}\mathrm{ran} \\
\mathrm{k}\end{array}$ & $\begin{array}{l}\text { Final } \\
\text { weig } \\
\text { ht }\end{array}$ & $\begin{array}{l}\text { Weak-ness } \\
\text { es }\end{array}$ & $\begin{array}{l}\mathrm{ran} \\
\mathrm{k}\end{array}$ & $\begin{array}{l}\text { Final } \\
\text { weig } \\
\text { ht }\end{array}$ & $\begin{array}{l}\text { Weak-ness } \\
\text { es }\end{array}$ & $\begin{array}{l}\text { ran } \\
\mathrm{k}\end{array}$ & $\begin{array}{l}\text { Final } \\
\text { weig } \\
\text { ht }\end{array}$ & $\begin{array}{l}\text { Weak-ness } \\
\text { es }\end{array}$ \\
\hline 1 & $\begin{array}{l}2049 . \\
6\end{array}$ & Tw1 & 1 & $\begin{array}{l}1837 . \\
1\end{array}$ & Ow1 & 1 & $\begin{array}{l}1890 . \\
8\end{array}$ & Sw1 & 23 & 578 & Ww10 & 1 & $\begin{array}{l}1845 . \\
2\end{array}$ & Ww1 \\
\hline 2 & $\begin{array}{l}1972 . \\
4\end{array}$ & Tw2 & 2 & 777.7 & Wv1 & 2 & $\begin{array}{l}1885 . \\
5\end{array}$ & Sw2 & 24 & 508.6 & Wi6 & 2 & $\begin{array}{l}1770 . \\
4\end{array}$ & Ww2 \\
\hline 3 & $\begin{array}{l}1962 . \\
8\end{array}$ & Tw3 & 3 & 491.5 & Ov2 & 3 & $\begin{array}{l}1815 . \\
6\end{array}$ & Sw3 & 25 & 499.2 & Wi7 & 3 & $\begin{array}{l}1661 . \\
2\end{array}$ & Ww3 \\
\hline 4 & 1372 & Tw4 & 4 & 325 & Ov3 & 4 & 997.8 & Si1 & 26 & 494.6 & Wi8 & 4 & $\begin{array}{l}1512 . \\
6\end{array}$ & Ws 1 \\
\hline 5 & $\begin{array}{l}1396 . \\
8\end{array}$ & Tw5 & 5 & 320 & Ov4 & 5 & 992.2 & Ss 1 & 27 & 491 & Wi9 & 5 & $\begin{array}{l}1466 . \\
6\end{array}$ & Ww4 \\
\hline 6 & $\begin{array}{l}1389 . \\
6\end{array}$ & Tw6 & 6 & 273.5 & Ov5 & 6 & 946.6 & Sw4 & 28 & 417.3 & Wv1 & 6 & $\begin{array}{l}1272 . \\
8\end{array}$ & Ws2 \\
\hline 7 & 874 & Tw7 & 7 & 269 & Oi1 & 7 & 942.8 & Sw5 & 29 & 365.1 & Wv9 & 7 & $\begin{array}{l}1272 . \\
4\end{array}$ & Ws3 \\
\hline 8 & 515.7 & Ts 1 & 8 & 256.4 & Os1 & 8 & 941.6 & Sw6 & 30 & 362.4 & Wv10 & 8 & $\begin{array}{l}1222 . \\
8\end{array}$ & Ws5 \\
\hline 9 & 438.2 & Tv2 & & & & 9 & 931.6 & Sw7 & 31 & 361.4 & Wv1 & 9 & $\begin{array}{l}1209 . \\
2\end{array}$ & Ws4 \\
\hline 10 & 399.3 & Ti1 & & & & 10 & 396.9 & Sv1 & 32 & 361.3 & Ws9 & 10 & $\begin{array}{l}1156 . \\
3\end{array}$ & Ws6 \\
\hline 11 & 361.1 & Tv3 & & & & 11 & 309.5 & Sv2 & 33 & 361 & Ws10 & 11 & $\begin{array}{l}1012 . \\
8\end{array}$ & Ww5 \\
\hline 12 & 350.7 & Tv4 & & & & & & & 34 & 354.1 & Wv2 & 12 & $\begin{array}{l}1001 . \\
6\end{array}$ & Ww6 \\
\hline
\end{tabular}




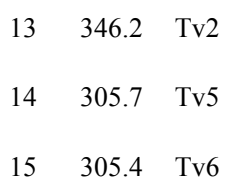

$\begin{array}{llllll}35 & 342.3 & \text { Ws11 } & 13 & 944.7 & \text { Ws7 } \\ 36 & 342 & \text { Ws12 } & 14 & 937.5 & \text { Ws8 } \\ 37 & 341.5 & \text { Wv3 } & 15 & 931.6 & \text { Ww7 } \\ 38 & 338 & \text { Wv4 } & 16 & 875.8 & \text { Wi1 } \\ 39 & 336.8 & \text { Wv5 } & 17 & 846 & \text { Ww8 } \\ 40 & 322.8 & \text { Ws13 } & 18 & 818.8 & \text { Ww9 } \\ 41 & 319.9 & \text { Wv7 } & 19 & 710 & \text { Wi2 } \\ 42 & 316.6 & \text { Wv8 } & 20 & 655 & \text { Wi3 } \\ & 7 & & & & \\ 43 & 254.9 & \text { Wi10 } & 21 & 649.4 & \text { Wi4 } \\ 44 & 254.6 & \text { Wi11 } & 22 & 630 & \text { Wi5 }\end{array}$

Results with the base of averages and various points of views are:

A) Transportation

1- The intensity and weakness:

1-1- The most principle weakness for internally BRTs

1-2- Varity's of transportation in Tehran

2- The most principle intensity:

2-1- the applicable altitude for 2 cabins bus for getting in for defective people

2-2- various appearances for 2 cabins bus

2-3- Facility in a congenial

3- Opportunities and threats:

3-1- the most significant opportunities

3-1-1- existing the condition for privatization under the elicit looking

3-1-2 treasure helping from budget

4-The most important threats (external)

4-1- no services and repairing and keeping cause of limitation and confining for buying busses

4-2- no treasure supporting for buying the developed bus

4-3- using insalubrious gas confronting from the environment

B) Stations:

1-The most vital weaknesses

1-1-Diminishing the passenger's security and the accessibility for pedestrian and sidewalks

1-2-Planning and building the inappropriately stations

1-3- lots of expenses for keeping the stations

C) Special lines for BRT

1- the most vital weaknesses (internal)

1-2- exactly lots of equals intersections

2- The most important internal strengths

2-1- separating the special BRT lines with fencing and the problem for pedestrian from the places that they are not designed 
3- The most principle for external opportunities:

3-1- increase safety of vehicle movement due to reduce pedestrian access due to build fence.

4- The most important external threats:

4-1- one-side of the lines

4-2- use the other cars from special lines and creating disturbance for buses

D) Management (ITS)

1-The most important intensities (internal)

1-1- not manipulating the management system

1-2- no existing the vital wisely systems in intersections

1-3- inappropriate behaving drivers

\section{Conclusion}

The compulsory need for accelerating teaching in all levels with the attention of pollution and transportation (Masumoto, 2010; Yuksel and Leviren, 2007).For supporting the teaching program in universities and making improvement the connection and information sharing with political experts in cities and the other areas can be vital. The vocational patterns for private organization are undeniable (Roberts and Skyes, 2000), Tehran city deserves having pure environment and healthy people. So cognation is vital investigations indicate that transportation BRT system in Tehran is having a good manipulation and in comparison with ordinary bus driving system has more performance. Diminishing time for waiting in station, accelerating speed for access to the target and healthy and security for passengers are the cause of people s approval and satisfaction. Consent between public transportation fleet in Tehran the most approval is about the under grounds and the approval average 49.91 from 100 with 17.47 standard devotion (table 6). Two benefits of BRT are the expenses are 10 times rather than line transporting and second the exerting speed that makes passengers satisfaction (Goodman and Laube, 1999).

Table 6. Distribution of Tehran citizens' satisfaction of public transport-2012

\begin{tabular}{ccc}
\hline Vehicle & Average & Standard deviation \\
\hline Metro & 4.13 & 1.44 \\
Bus & 3.23 & 1.35 \\
Taxi & 3.42 & 1.2 \\
Taxi Agency & 3.19 & 1.33 \\
\hline
\end{tabular}

The investigation has some consequence from passenger's satisfaction and it has some relation between passengers and nimble buses, also the function for treatment between workers behavior has the 1.99 average in the first rank also the acceleration of BRT system has 2.04 average in the second steps environment engineering has the third rank with average of 2.87 and also BRT system with average of 3.10 in the 4th Sep.

High speed with qualified buses with the applicable quality has lots of quantities and capacities so the entering and exiting would be so comfortable besides the developed innovations the majority of passengers they are choosing BRT system. So it observes lots of passengers on Tehran this systems transport 500,000 people paring a day observing folks the other transportation system line private vehicle, taxies, etc. are so highlighted and principle. But $50 \%$ of people one utilizing BRT systems so it indicates the traffic has been descend and also pollution going to be diminished. Another benefit for BRT is peoples points of views for the buses become better these days and abort $41 \%$ of workers in BRT are almost educated with high level of services in a modern direction. The $250 \%$ increasing of BRT system passengers in studying line has the $33 \%$ rebate vacation time in comparison with before and also $22 \%$ bus fleet with acceleration the benefit and diminishing the polluted gases. Another benefit of BRTs system is providence in time expenditure the merit would be 50 billion in a year (TTST, 2007).Another point to be noted is that, BRT system compared to another system is be proportional to 
government agencies to implement ( Karbassi et al.,2012). All the above indicates acceptable performance for BRT system compared to the previous ordinary bus system. BRT system also has some problems and negative points that solving the makes people satisfaction with the lowest treasure. We have 6350 fleet they wouldn't be adequate so we should do some significant exerting for reducing the percentage of pollutions, traffic and developing the transportation system.

\section{References}

Afandizadeh, S., \& Baghaee, A. (2008). Methodology design of routing for buses in urban areas, Proceeding of the first Civil Engineering Congress, Sharif University, Tehran, Iran.

Amin, S. H., Razmi, J., \& Zhang, G. (2011). Supplier selection and order allocation based on fuzzy SWOT analysis and fuzzy linear programming, Expert Systems with Applications, p 38.

Bulgaria, M. (2004). Laws and regulations of transportation, Transportation and Traffic Division, Homage Danesh Pub., Tehran, Iran.

Chang, H., Huang, H., \& W. Ch. (2006). Application of a quantification SWOT analytical method, Mathematical and Computer modeling, p43.

Cheng, Y., Lin, Y., \& Liu, C. (2007). Levels of PM 10 and PM2.5 in Taipei Rapid Transit System, Department of Safety, Health and Environmental Engineering. Ming Chi University of Technology, Taiwan.

Chuanjiao, S., ZHOU, W., \& Yuanqing, W. (2008). Scheduling Combination and Headway Optimization of Bus Rapid Transit, Highway, College of Changan University, Xian, China.

CTBU-Company of Tehran and Suburbs Buses United. (2009). Statistics of public buses and BRT passengers, CTBU, Tehran, Iran.

Dill, J. (2006). Travel and transit use at Portland area transit oriented developments (TODs), University of Washington.

DUA-Deputy of Urbanization and Architecture. (2007). Integrating of Tehran urban development problems: land use studies, Municipality of Tehran, Tehran, Iran.

FTA- Federal Transit Administration Office of Research, Demonstration and Innovation. (2009). Characteristics of Bus Rapid Transit for decision making, U.S.

Goodman, J., \& Laube, M. (1999). Issues in Bus Rapid Transit. Federal Transit Administration.

Gwillian, K., Kojima, M., \& Johnson, T. (2010). Reducing Air Pollution from urban transport Washington: The World Bank.

Hiroyuki, I. (2008). Economies of scale in bus transit service in the USA, Department of Geography and Planning, The University of Toledo, Toledo, OH, United States.

Kajanus, M., Kangas, J., \& Kurttila, M. (2004). The use of value focused thinking and the A WOT hybrid method Tourism Management, $\mathrm{p} 25$.

Karbassi, A. R., Monavari, S. M., \& Azarkamand, S. (2012). Strategies for urban environment management, Talab Pub., Tehran, Iran.

Kurttila, M., Pesonen, M., Kangas, J., \& Kajanus, M. (2000). Utilizing the analytic hierarchy process (AHP) in SWOT analysis - a hybrid method and its application to a forest-certification case, Forest Policy and Economics, $\mathrm{p} 1$.

Monavari, S. M., \& Aminsharee, F. (2010). Engineering and management of municipal solid waste collection, Amir Kabir Jahad Daneshgahi Pub., Tehran, Iran.

Municipality of Tehran. (2004). Estimation of social-economic statistics of citizens travel in Tehran-2020, Transportation and Traffic Division, Tehran, Iran.

Municipality of Tehran. (2008). Tehran, Center of Researches and Planning, Tehran, Iran.

Poormoallem, N., Kianpoor, M., \& Bangesh, M. J. (2008).Evaluation of urban development politics for public transportation on metro stations. Journal of Traffic Management Studies, 3, 9, Tehran, Iran.

Roberts, P., \& Sykes, H. (2000). Urban Regeneration, SAGE Publication, London, UK.

Syed, S. J., \& Khan, A. M. (2000). Factor Analysis for the Study of Determinants of Public Transit Ridership, Journal of Public Transportation. 
Taleai, M., Mansourian, A., \& Sharifi, A. (2009). Surveying general prospects and challenges of GIS implementation in developing countries: a SWOT-AHP approach. Journal of Geographical System, 11, 3.

TTST-Tehran Transportation and Traffic Studies Company. (2006). Tehran transportation and traffic master plan, Deputy of Transportation and Traffic, Municipality of Tehran, Tehran, Iran.

TTST-Tehran Transportation and Traffic Studies Company. (2007). Tehran transportation and traffic in glance, Deputy of Transportation and Traffic, Municipality of Tehran, Tehran, Iran.

Yuksel, I., \& Leviren, M. D. (2007). Using the analytic network process (ANP) in AWOT analysis- a Case study for textile firm, Information Sciences, no 177.

Zamanian, A., Ghafghazi, I., \& Eghbalian, A. (2010). Economic-environmental Assessment of second line BRT in Tehran, Proceeding of the 9th Conference of Transportation and Traffic Engineering in Iran, Tehran, Iran.

\section{Copyrights}

Copyright for this article is retained by the author(s), with first publication rights granted to the journal.

This is an open-access article distributed under the terms and conditions of the Creative Commons Attribution license (http://creativecommons.org/licenses/by/3.0/). 